\title{
Pertanggungjawaban Koorporasi PT Bank BNI, Tbk, dalam Kredit Macet Berdasarkan Undang-undang Nomor 20 Tahun 2001 tentang Pemberantasan Tindak Pidana Korupsi
}

\author{
Fitria Kusumawardhani * \\ Universitas Lancang Kuning
}

*Corresponding author: E-mail: fitriakusumawardhani@rocketmail.com

\begin{abstract}
Abstrak
Dalam artikel ini membahas kasus yang akan digunakan sebagai bahan studi dalam artikel ini kasus Kinerja kredit PT BANK NEGARA INDONESIA Tbk (BNI) yang kinclong pada 2016 harus diimbangi dengan peningkatan rasio bermasalah (Non Performing Loan/NPL) sepanjang tahun lalu. Tercatat, sepanjang 2016 angka NPL gross perseroan merangkak naik menjadi 3 persen dari posisi 2015 yang hanya sebesar 2,7 persen. Direktur Business Banking BNI Putrama Wahju Setiawan mengatakan, peningkatan kredit macet tersebut diakibatkan oleh macetnya pembayaran kredit yang dilakukan oleh dua debitur segmen korporasi yang memiliki jumlah utang cukup besar. Kedua perusahaan tersebut adalah PT Trikomsel Oke Tbk dan PT Pan Maritime. Dalam pembahasan tentang pertanggungjawaban koorporasi dalam tindak pidana koorporasi Undang - Undang Nomor 31 Tahun 1999 tentang Tindak Pidana Koorporasi, yang akan membahas mengenai pertanggung jawaban susunan koorporasi dalam kasus Bank BNI.
\end{abstract}

Kata kunci : Pertanggungjawaban Koorporasi, PT Bank BNI, Tbk, Kredit Macet

\begin{abstract}
In this article discuss the case that will be used as study material in this article case The credit performance of PT BANK NEGARA INDONESIA Tbk (BNI) which kinclong in 2016 must be balanced with the increase of Non Performing Loan (NPL) over the past year. Recorded, throughout 2016 the gross NPL rate of the company crept up to 3 percent from the position of 2015 which only amounted to 2.7 percent. Director of Business Banking BNI Putrama Wahju Setiawan said the increase in non-performing loans was caused by the stalled credit payments made by two corporate segment debtors with large amount of debt. The two companies are PT Trikomsel Oke Tbk and PT Pan Maritime. In the discussion of corporation accountability in the koorporasi criminal act Act No. 20 of 2001 on Criminal Acts, which will discuss the accountability of the composition of the corporation in the case of Bank BNI.
\end{abstract}

Keyword: Coorporate Responsibility, PT. Bank BNI, Tbk, Bad Credit

How to Cite: Kusumawardhani, F., (2018), Pertanggungjawaban Koorporasi PT Bank BNI, Tbk, dalam Kredit Macet Berdasarkan Undang-undang Nomor 20 Tahun 2001 tentang Koorporasi, Mercatoria, 11 (1): 1-19. 
Fitria Kusumawardhani, Pertanggungjawaban Koorporasi PT Bank BNI, Tbk, dalam Kredit Macet Berdasarkan Undang-undang Nomor 20 Tahun 2001 tentang Koorporasi

\section{PENDAHULUAN}

Indonesia termasuk ke dalam negara hukum modern, karena memenuhi ciri-ciri hukum modern, artinya Pemerintah ikut campur dalam segala lapangan kehidupan masyarakat. Salah satu ciri dari negara hukum modern adalah corak negara "welafre State" yaitu suatu negara yang mengutamakan kepentingan seluruh rakyat dan sistem ekonomi lebih dipimpin oleh pemerintah pusat (central geleide ekonomie).

Negara kesejahteraan (welfare state) adalah negara hukum yang memusatkan perhatian pada upaya mewujudkan kesejahteraan orang banyak UUD 1945 baik dalam pembukaan maupun batang tubuh memuat berbagai ketentuan yang melestarikan kewajiban pada negara atas pemerintah untuk mewujudkan kesejahteraan pada orang banyak. Bahkan sila ke - 5 Pancasila dengan tegas menyatakan prinsip "keadilan sosial bagi seluruh rakyat Indonesia". Elemen-elemenya adalah kekuasaan pemerintah berdasarkan peraturan hukum, dan peradilan administrasi negara.

Keadilan berdasarkan prinsip perbedaan diartikan bahwa perbedaan sosial dan ekonomi dalam masyarakat yang sebesar-besarnya terhadap orangorang yang kurang beruntung, dan memberikan kesempatan dan posisi yang sama kepada semua dengan persyaratan yang sama. Semua kategori konsep keadilan itu disebut keadilan substantif yang memerlukan keadilan prosedural. Bagi John Rawls keadilan prosedural tidak dpat dilepaskan dari substansinya. Substansi dan proses penegakkan keadilan sama pentingnya. Semua bentuk keadilan dapat dilihat dengan mempertanyakan bagaimana keadilan itu direalisasikan, karena hanya dapat dengan prosedur yang fair dapat menghasilkan hasil yang adil, mengenai penegakkan, mengandung ketentuan bersifat mengatur dan memaksa. Hukum dalam pandangan L.J Van Apeldorn adalah untuk mengatur tata tertib dalam masyarajat secara damai dan adil.

Pandangan hidup bangsa Indonesia telah dirumuskan secara padat bentuk kesatuan rangkaian lima sila yang dinamakan Pancasila (Rani Sri Agustina, 2016). Pancasila sebagai filosofi negara indonesia. Konsep negara modern reformasi demokrasi berasal dari prinsip konstitusi. Pendapat Friedrich, negara yang mana adalah proses pembaharuan demokrasi, prinsip konsititusi salah satunya bagaimana selalu memberikan efektif, terlebih aturan dan pengamanan pemerintahan negara (The Philosophy of Pancasila).

Menurut Habib Adjie, pada masa yang akan datang, secara umum sistem hukum modern bercirikan :

1) Fasilitas, yaitu hukum yang dapat memfasilitasi berbagai kepentingan hukum, artinya segala hal yang dibutuhkan oleh masyarakat hukum telah memberikan jalannya.

2) Akomodatif, yaitu hukum yang dapat mengakomodasikan berbagai kepentingan masyarakat, artinya apa yang dibutuhkan oleh masyarakat, hukum telah memberikan jalannya.

3) Adaptif, yaitu hukum yang dapat beradaptasi dengan hal-hal yang baru yang terjadi tetap memberikan kepastian hukum dan 
tetap dengan memberikan perhatian terhadap hukum yang lama sehingga dalam hal ini hukum harus dapat mengintegrasikan berbagai nilai lama dan hal-hal yang baru sehingga terjadi perubahan, tidak menimbulkan gejolak yang mengakibatkan kekosongan hukum.

4) Bottom Up, bahwa hukum merupakan kristalisasi berbagai nilai yang hidup dalam masyarakat selama ini, artinya nilai-nilai yang selama ini hidup dalam masyarakat dan nilai-nilai tersebut diyakini sesuatu yang benar, maka harus dihargai dan dinormatifkan dalam bentuk seuatu peraturan perundang-undangan.

5) Futuristik, yaitu hukum yang dapat mengantisipasi berbagai kejadian yang mungkin muncul pada suatu hari. Meskipun suatu tindakan hukum tidak diatur dalam peraturan perundang-undangan, hukum yang futuristik telah memberikan jalan keluarnya (Emma Nurita, 2012).

Lembaga perbankan merupakan untuk dari sistem keuangan dari setiap negara. Bank adalah lembaga keuangan yang mejadi tempat bagi orang perseorangan, badan-badan usaha swasta, badan-badan usaha milik negara, bahkan lembagalembaga pemerintahan menyimpan danadana yang dimilikinya. Melalui kegiatan perkreditan dan berbagai jasa yang diberikan, bank melayani kebutuhan pembiayaan serta melancarkan mekanisme sistem pembayaran bagi semua sektor perekonomian.
Menurut Prof. G. M. Verryn Stuart, dalam bukunya, Bank Politik, berpendapat bahwa bank adalah suatu badan yang bertujuan untuk memuaskan kebutuhan kredit, baik dengan alat-alat pembayarannya sendiri atau dengan yang diperolehnya dari orang lain, maupun dengan jalan mengedarkan alat-alat penukar baru berupa uang giral.

Pasal 1 butir 2 Undang-Undang Nomor 10 Tahun 1998 tentang Perbankan merumuskan bahwa bank adalah badan usaha yang menghimpun dana dari masyarakat dalam bentuk simpanan dan menyalurkannya kepada masyarakat dalam bentuk kredit dan/atau bentukbentuk lainnya dalam rangka meningkatkan taraf hidup rakyat banyak (Chartamarrasjid, Ais, 2009).

Bank dibentuk dalam bentuk Perseroan Terbatas (PT). Menurut Undang-Undang Nomor 40 Tahun 2007 pendirian PT harus dilakukan minimal oleh dua orang warga negara Indonesia (WNI) yang telah mampu dan cakap untuk berbuat hukum.

Dalam artikel ini membahas kasus yang akan digunakan sebagai bahan studi dalam artikel ini kasus Kinerja kredit PT BANK NEGARA INDONESIA Tbk (BNI) yang kinclong pada 2016 harus diimbangi dengan peningkatan rasio bermasalah (Non Performing Loan/NPL) sepanjang tahun lalu. Tercatat, sepanjang 2016 angka NPL gross perseroan merangkak naik menjadi 3 persen dari posisi 2015 yang hanya sebesar 2,7 persen.

Direktur Business Banking BNI Putrama Wahju Setiawan mengatakan, peningkatan kredit macet tersebut diakibatkan oleh macetnya pembayaran kredit yang dilakukan oleh dua debitur 
Fitria Kusumawardhani, Pertanggungjawaban Koorporasi PT Bank BNI, Tbk, dalam Kredit Macet Berdasarkan Undang-undang Nomor 20 Tahun 2001 tentang Koorporasi

segmen korporasi yang memiliki jumlah utang cukup besar. Kedua perusahaan tersebut adalah PT Trikomsel Oke Tbk dan PT Pan Maritime.

Dalam pembahasan tentang pertanggungjawaban koorporasi dalam tindak pidana koorporasi Undang Undang Nomor 20 Tahun 2001 tentang Pemberantasan Tindak Pidana Korupsi, yang akan membahas mengenai pertanggung jawaban susunan koorporasi dalam kasus Bank BNI.

Berdasarkan uraian tersebut diatas, maka permasalahan yang akan di bahas dalam artikel ini adalah

1. Bagaimanakah pertanggungjawaban koorporasi Bank BNI dalam Kredit Macet Berdasarkan Undang-Undang Nomor 20 Tahun 2001 tentang Pemberantasan Tindak Pidana Korupsi ?

\section{METODE PENELITIAN}

Penelitian hukum merupakan upaya untuk mencari dan menemukan pengetahuan yang benar mengenai hukum. Mencari dan menemukan itu tentu saja ada caranya, yaitu melalui metode (M. Syamsudin, 2007). Dalam penelitian ini menggunakan penelitian normatif, yaitu melakukan kajian terhadap berbagai peraturan perundang-undangan yang berkaitan dengan Pertanggungjawaban Koorporasi PT Bank BNI, Tbk, dalam Kredit Macet Berdasarkan Undang-undang Nomor 31 Tahun 1999 tentang Pemberantasan Tindak Pidana Korupsi. Penelitian hukum normatif atau penelitian hukum kepustakaan adalah penelitian hukum yang dilakukan dengan cara meneliti bahan pustaka atau bahan sekunder belaka (Soerjono Soekanto dan Sri Mamudji,
2001). Di dalam penelitian hukum normatif, maka penelitian terhadap asas-asas hukum dilakukan terhadap kaidah-kaidah hukum, yang merupakan patokan-patokan berprilaku atau bersikap tidak pantas (Nomensen Sinamo, 2009).

\section{HASIL DAN PEMBAHASAN}

Perseroan Terbatas telah berdiri apabila sudah ditandatangannya akta pendirian yang dibuat oleh pediri di hadapan notaris. Namun, PT memperoleh status badan hukum pada tanggal diterbitkannya Keputusan Menteri mengenai pengesahan badan hukum Perseorang Terbatas yang permohonannya dilakukan menutu prosedur pengajuan permohonan badan hukum PT via internet melalui Sistem Administrasi Badan Hukum (SABH). Dengan kata lain, berdirinya PT yang ditandai dengan telah dibuatnya akta pendirian PT belumlah menjadikan PT bisa berbuat hukum sendiri karena PT sebenarnya belum berbadan hukum. Namun, para pendiri tetap bisa berbuat hukum dengan ketentuan akan tetap masih di diri tetap bisa berbuat hukum dengan ketentuan akan tetap masih dianggap bahwa dalam hal ini pendiri bertanggung jawab secara pribadi (Adib Bahari, 2013).

Macam-macam Perseroan Terbatas

\section{Perseroan Tertutup (PT Biasa)}

yakni jenis Perseroan Terbatas sebagaimana diatur oleh Pasal 1 UndangUndang Nomor 40 Tahun 2007 tersebut, yaitu badan hukum yang merupakan persekutuan modal, didirikan berdasarkan perjanjian, melakukan kegiatan usaha dengan modal dasar yang seluruhnya terbagi dalam saham, dan memnuhi 
persyaratan yang ditetapkan dalam Undang-Undang Nomor 40 Tahun 2007 tentang Perseroan Taerbatas, serta peraturan pelaksanaannya.

\section{Perseroan Terbuka (PT Tbk)}

yakni perseroan publik atau perseroan yang melakukan penawaran umum saham di pasar modal, sesuai dengan ketentuan peraturan perundangundangan di bidang pasar modal. Perseroan terbuka menjual sahamnya kepada masyarakat melalui pasar modal go publik). Sahamnya ditawarkan kepada umum, diperjualbelikan melalui bursa saham dan setiap orang berhak untuk membeli saham perusahaan tersebut. Tanda lahirlah yang mudah dipahami oleh masyarakat adalah penyebutan nama PT selalu didahului oleh frasa "Perseroan Terbatas" atau disingkat PT dan diakhiri dengan tambahan singkatan Tbk.

\section{Pengertian Bank}

Lembaga perbankan sebagai salah satu lembaga keuangan mempunyai nilai strategirs dalam kehidupan perekonomian suatu negara. Lembaga tersebut dimaksudkan sebagai perantara pihakpihak yang mempunyai kelebihan dana (surplus of funds) dengan pihak-pihak yang kekurangan dana (lack of funds). Perbankan bergerak dalam berbagai jasa yang diberikan seperti kegiatan perkreditan, juga melayani kebutuhan pembiayaan serta melancarkan mekanisme sistem pembayaran bagi semua sektor perekonomian.

Definisi bank menurut Pasal 1 butir ke-2 Undang-Undang Nomor 7 Tahun 1992 sebagaimana telah diubah oleh Undang-Undang Perbankan Nomor 10 Tahun 1998 tentang Perbankan (yang selanjutnya disebut Undang-Undang Perbankan)

"Badan Usaha yang menghimpun dana dari masyarakat dalam bentuk simpanan dan meyalurkannya kepada masyarakat dalam kredit dan/atau bentuk-bentuk lainnya dalam rangka meningkatkan taraf hidup orang banyak."

Fungsi bank sebagaimana ditulis dalam Undang-Undang Perbankan Pasal 1 ayat (2) adalah financial intermediary yaitu sebagai lembaga atau badan usaha yang memiliki fungsi sebagai penghimpun dan menyalurkan dana masyarakat serta memberikan jasa-jasa lainnya yang lazin dalam bank dalam lalu lintas pembayaran. Bismar mengatakan bahwa bank memiliki 5 (lima) fungsi pokok yaitu :

1. Menghimpun dana;

2. Memberi kredit;

3. Memperlancar lalu lintas pembayaran;

4. Media kebijakan moneter;

5. Penyedia informasi, pemberian konsultan bantuan penyelenggaraan administrasi.

\section{Susunan Organisasi Perseoran Terbatas}

Susunan organisasi lingkup intern perbankan ialah Direksi, Komisaris, Anggota Komisaris.

\section{Direksi}

Menurut Pasal 1 UUPT Nomor 40 Tahun 2007, yang dimaksud dengan Direksi adalah organ perseroan yang berwenang dan bertanggung jawab penuh atas pengurusan perseroan untuk kepentingan perseroan sesuai dengan maksud dan tujuan perseroan, serta mewakili perseroan baik di dalam maupun di luar pengadilan, sesuai dengan ketentuan Anggaran Dasar PT. Orang yang 
Fitria Kusumawardhani, Pertanggungjawaban Koorporasi PT Bank BNI, Tbk, dalam Kredit Macet Berdasarkan Undang-undang Nomor 20 Tahun 2001 tentang Koorporasi

menjabat sebagai anggota Direksi disebut Direktur. Direktur Perseroan bisa berdiri dari satu orang anggota Direksi atau lebih. Namun, dalam hal perseroan yang kegiatan usahanya berkaitan dengan menghimpun dan/atau mengelola dana masyarakat, perseroan yang menerbitkan surat pengakuan utang kepada masyarakat, atau perseroan terbuka wajib mempunyai paling sedikit dua anggota Direksi atau lebih, pembagian tugas dan wewenang pengurusan di antara anggota Direksi ditetapkan berdasarkan keputusan RUPS.

Pengurusan PT wajib dilaksanakan setiap anggota Direksi dengan itikad baik dan penh tanggung jawab, hal ini penting mengingat terdapat ketentuan bahwa setiap anggota Direksi bertanggung jawab penuh secara pribadi atas kerugian perseroan apabila yang bersangkutan bersalah atau lalai menjalankan tugasnya.

Namun, anggota Direksi tidak dapat dipertanggungjawabkan atas kerugian PT apabila mereka dapat membuktikan :

1. Kerugian tersebut bukan karena kesalahan atau kelalainnya;

2. Telah melakukan pengrusan dengan iktikad baik dan kehati-hatian untuk kepentingan dan sesuai dengan maksud dan tujuan perseroan;

3. Tidak mempunyai benturan kepentingan, baik langsung maupun tidak langsung atas tindakan pengurusan yang mengakibatkan kerugian;

4. Telah mengambil tindakan untuk mencegah timbul atau berlanjutnya kerugiatan tersebut.

\section{Dewan Komisaris}

Menurut Pasal 1 UUPT, yang dimaksud dengan Dewan Komisaris adalah organ perseroan yang memiliki dua tugas utama, yakni :

1. Melakukan pengawasan secara umum dan/atau khusus sesuai dengan Anggara Dasar terhadap PT (Direksi); dan

2. Memberi nasihat kepada Direksi

Peran Dewan Komisaris dalam garis besarnya sebagai berikut :

1. Dewan Komisaris melakukan pengawasan atas kebijakan pengurusan, jalannya pengurusan pada umumnya, baik mengenai PT maupun usaha PT, dan memberi nasihat kepada Direksi;

2. Setiap anggota Dewan Komisaris wajib dengan iktikad baik, kehatihatian dan bertanggung jawab dalam menjalankan tugas pengawasan serta pemberian nasihat kepada Direksi untuk kepentingan PT dan sesuai dengan maksud serta tujuan PT (Adib Bahari, 2013).

\section{Pengertian Kredit}

Penandatangan proses pengajuan kredit berada di tangan anggota direksi. Jangka waktu kredit perbankan untuk masyarakat ialah pendek, menengah, panjang.

1. Kredit jangka pendek (short-term loan), yaitu kredit yang jangka waktu pengembaliannya kurang dari satu tahun.

2. Kredit jangka menengah (mediumterm loan), kredit yang jangka waktu pengembaliannya satu sampai tiga tahun. 
3. Kredit jangka panjang (long-term loan), yaitu kredit yang jangka waktu pengembaliannya melebihi tiga tahun.

Menurut jaminan kredit dapat diklasifikasikan menjadi :

1. Kredit dengan jaminan (secured loan)

Kredit yang disertai penyerahan barang jaminan oleh nasabah. Misalnya kredit untuk pembelian mobil atau motor, jaminannya BPKB mobil atau motor tersebut.

2. Kredit tanpa jaminan (Unsecured loan)

Kredit yang tidak disertai penyerahan barang jaminan dan nasabah. Jenis kredit ini tidak menggunakan jaminan dari nasabah. Jenis kredit ini tidak menggunakan jaminan dalam bentuk fisik, tetapi dalam bentuk bonafiditas dan prospek usaha nasabah yang bersangkutan. Pemberian kredit tanpa jaminan ini dilakukan sepanjang prinsipprinsip penilaian kredit lainnya telah terpenuhi menurut analsisis kredit.

3. Kredit Produktif (Produktif Loan)

Kredit yang diberikan oleh suatu perusahaan dalam rangka membiayai kebutuhan modal kerja debitur sehingga dapat memperlancar produksi.

Menurut Penggunaannya kredit dapat digolongkan menjadi :

a. Kredit modal kerja

Kredit yang diberikan oleh suatu perusahaan untuk menambah modal kerja debitur

b. Kredit investasi

Kredit yang diberikan oleh suatu perusahaan kepada perusahaan untuk digunakan dalam melakukan investasi melalui pembelian barang-barang modal.

\section{Pengertian Kredit dalam KUHPerdata}

Pengertian kredit adalah persetujuan atau kesepakatan pinjamanmeminjam. Perjanjian pasal 1313 KUHPerdata "suatu perbuatan dengan mana satu orang atau lebih mengikatkan dirinya terhadap satu orang lain atau lebih."

Dasar hukum perjanjian kredit adalah pinjam-meminjam yang didasaran pada kesepakatan antara debitur-kreditur. Pinjam-meminjam diatur dalam Buku III bab XIII khususnya Pasal 1754-1769 KUHPerdata.

R. Soebekti tentang asas kebebasan berkontrak, asas ini bermakna bahwa setiap orang atau masyarakat bebas membuat perjanjian dengan siapapun, apapun isinya, apapun bentuknya sejauh tidak melanggar undang-undang, ketertiban umum dan kesusilaan (pasal 1337-1338 KUHPerdata), asas kebebasan berkontrak memberikan kebebasan kepada para pihak untuk :

1. Membuat atau tidak membuat perjanjian

2. Mengadakan perjanjian dengan siapapun

3. Menentukan isi perjanjian, pelaksanaan, dan persyaratannya

4. Menentukan bentuk perjanjian, yaitu secara tertuis atau lisan

5. Keempat tersebut dilakukan dengan syarat tidak melanggar undangundang, ketertiban umum, dan kesusliaan.

Pengertian pinjam-meminjam sendiri menurut Pasal 175 KUHPerdata adalah "perjanjian dengan mana pihak yang memberikan kepada pihak yang lain suatu jumlah tertentu barang-barang yang menghabis karena pemakaian, dengan 
Fitria Kusumawardhani, Pertanggungjawaban Koorporasi PT Bank BNI, Tbk, dalam Kredit Macet Berdasarkan Undang-undang Nomor 20 Tahun 2001 tentang Koorporasi

syarat bahwa pihak yang belakangan ini akan mengembalikan sejumlah yang sama dari macam dan keadaan yang sama pula.

Pasal 1765 KUHPerdata disebutkan bahwa "selanjutnya diperbolehkan memperjanjikan, bunga atas peminjaman uang atau lain barang yang menghabis karena pemakaian." Aspek riil, perjanjian ini tunduk pada UUP dan ketentuan yang terdapat dalam model-model perjanjian (standar) kredit yang digunakan di lingkungan perbankan, perjanjian kredit dalam aspeknya yng riil ini tidak tunduk pada Bab XIII Buku III KUHPerdata (Handri Raharjo, 2010).

\section{Pengertian Hukum Acara Perdata}

Salah satu pembagian hukum secara ortodoks (the orthodox classification) adalah pembedaan antara dua bidang hukum :

a. Substantive Law

b. Procedursl Law Menurut Patton, hukum materiil (subtantive law) mengatur hak kewajiba juga bersifat pemulihan hak berisikan hak dan kewajiban. Pemulihak hak adalah kemampuan untuk memulihkan kembali hak melalui ganti kerugian. Menciptakan hak dan kewajiban :

a. Hak untuk menuntut ganti kerugian

b. Kebebasan untuk menuntut

c. Kebebasan untuk memulihkan haknya

d. Kekebalan (immunities)

\section{Pengertian Alat Bukti}

Alat bukti jelas adalah alat untuk membuktikan kebenaran hubungan hukum, yang dinyatakan baik oleh penggugat maupun oleh tergugat dalam perkara perdata. Alat bukti itu adalah sesuatu yang sebelum diajukan ke persidangan, memang sudah berfungsi sebagai alat bukti. Klasifikasi alat bukti terbagi atas :

1. Oral

2. Documentary

3. Material

Alat bukti oral adalah alat bukti yang diucapkan secara lisan, termasuk kesaksian dan sumpah.

Alat bukti "documentary" adalah yang dunia hukum kita indonesia dinamai "alat bukti tertulis"

Alat bukti "material" adalah alat bukti dalam wujud benda konkret, selain pada alat bukti tertulis.

Pembagian menurut Prof. R. Subekti, S.H

1. Alat bukti langsung, misalnya alat bukti tertulis dan kesaksian

2. Alat bukti yang tidak langsung, yaitu

Alat-Alat menurut Undang-Undang (BW, HIR dan R.bg) pada dasarnya membagi alat bukti dalam hukum acara perdata :

1. Alat bukti tertulis atau surat,

2. Kesaksian,

3. Persangkaan-persangkaan,

4. Pengakuan,

5. Sumpah,

6. Keterangan Ahli (expertise),

7. Pemeriksaan setempat (descente)

Pengertian Korupsi dari berbagai aspek bergantung dari disiplin ilmu yang menjadi titik pijak, dari segi bahasa, sosiologi, antropologi, ekonomi dan hukum dapat menghasilkan defenisi yang berbeda mengenai korupsi. Definisi atau batasan korupsi ini menjadi penting karena menjelaskan perbuatan yang dianggap tercela atau melawan hukum 
(wederrechtelijkheid) di antara sejarah pemberantasan korupsi di Indonesia.

\section{Sejarah Pemberantasan Korupsi}

Dalam sejarah pemberantasan korupsi di Indonesia, pengertian korupsi dalam Undang-Undang

Pemberantasan Tindak Pidana Korupsi (PTPK), khususnya mengenai penempatan unsur melawan dalam konteks onrechtmatigedaad pada pasal 2 ayat (1) Undang-Undang Nomor 31 Tahun 1999 tentang Pemberantasan Tindak Pidana Korupsi Jo atas Undang-Undang 20 Tahun 2001 tentang Perubahan atas UndangUndang Nomor 31 Tahun 1999 tentang Pemberantasan Tindak Pidana Korupsi (UUPTPK) Jo. Nomor 20 Tahun 2001 telah mempunyai kekuatan hukum mengikat, melalui putusan Mahkamah Konsitusi Nomor 003/PUU-IV/2006 atas gugatan peninjauan kembali (judicial review).

Korupsi dalam bahasa latin disebut Corruptio - Corruptus, dalam Bahasa Belanda disebut corruptie, dalam Bahasa Inggris disebut corruption, dan dalam Bahasa Sansekerta yang tertuang dalam Naskah Kuno Negara Kertagama arti harfiah corrupt menunjukkan kepada perbuatan yang rusak, busuk, bejad, tidak jujur yang disangkutpautkan dengan keuangan.

Menurut Robert Klilgaard, yang mengupas korupsi dari perspektif administrasi negara, mendefenisikan korupsi sebagai tingkah laku yang menyimpang dari tugas-tugas resmi sebuah jabatan negara kerena keuntungan status atau uang yang menyangkut pribadi (perorangan, keluarga, kelompok sendiri) atau aturan pelaksanaan menyangkut tingkah laku pribadi.
Menurut Syed Hussein Alatas, secara tipologis korupsi dapat dibagi dalam 7 (tujuh) jenis yang berlainan. Masing-masing adalah :

1. Korupsi Transaktif (transactive corrption)

2. Korupsi yang memeras (extrotive corruption)

3. Korupsi Investif (investive corruption)

4. Korupsi perkerabatan (nepotistic corruption)

5. Korupsi Defensif (defensive corruption)

6. Korupsi Otogenik (autogenic corruption)

7. Korupsi Dukungan (supportive corrption)

Wold bank mendefenisikan korupsi sebagai an abuse of public power for private gains (suatu penyalahgunaan kekuasaan untuk kepentingsn pribadi), dengan bentuk - bentuk dari korupsi tersebut antara lain sebagai berikut :

a. Political Corruption (Grand Corruption), yang terjadi ditingkat tinggi (penguasa, politisi, pengambil keputusan) dimana mereka memiliki suatu kewenangan untuk memformulasikan, membentuk dan melaksanakan undang-undang atas nama rakyat, dengan memanipulasi insitusi politik, aturan prsedural dan distorsi lembaga pemerintahan, dengan tujuan meningkatan kekayaan dan kekuasaan;

b. Bureaucratic Corruption (Petty Corruption), yang biasa terjadi dalam administrasi publik seperti 
Fitria Kusumawardhani, Pertanggungjawaban Koorporasi PT Bank BNI, Tbk, dalam Kredit Macet Berdasarkan Undang-undang Nomor 20 Tahun 2001 tentang Koorporasi

di tempat-tempat pelayanan umum;

c. Electoral Corruption (Vote Buying) dengan tujuan untuk memenangkan suatu persaingan seperti dalam Pemilu, Pilkada, Keputusan Pengadilan, Jabatan Pemerintahan, dan sebagainya.

d. Private or Individual Corruption, korupsi yang bersifat terbatas, terjadi akibat adanya kolusi atau konsiparasi antar individu atau teman dekat;

e. Collective or Aggregated Corruption, dimana korupsi dinikmati

Delik-delik yang dapat merugikan keuangan negara atau perekonomian negara

Pasal 2 ayat 1, diancam dengan pidana penjara seumur hidup atau pidana penjara paling singkat 4 (empat) tahun dan paling lama 20 (dua puluh) tahun dan denda paling sedikit Rp 200.000.000 (dua ratus juta rupiah) dan paling banyak Rp 1.000.000.000 (satu miliar rupiah).

Unsurnya terdiri :

a. Setiap orang

b. Secara melawan hukum

c. Melakukan perbuatan memperkaya diri sendiri atau orang lain atau suatu korporasi

d. Dapat merugikan keuangan negara atau perekonomian negara

\section{Pengertian Orang}

Pengertian setiap orang dalam pasal ini, siapa saja yang dapat dipertanggungjawaban secara hukum, baik dalam kapasitasnya sebagai pegawai negeri, pihak swasta atau korporasi.

Dalam tindak pidana korupsi memang pengertian subyek hukum berupa setiap orang tidak terbatas kepada orang perorangan, tetapi juga korporasi yang merupakan "kumpulan orang atau kekayaan yang terorganisasi baik merupakan badan hukum maupun bukan badan hukum."

Keterliban korporasi dalam tindak pidana diposisikan sebagai subyek hukum, tidak saja menimbulkan persoalan tentang hak melakukan tindak pidana, tetapi juga masalah-masalah pertanggungjawaban korporasi. Diterimanya korporasi dalam pengertian badan hukum atau konsep pelaku fungsional ( functional daderschap ) dalam hukum pidana merupakan perkembangan yang sangat maju dengan meggeser doktrin yang mewarnai wetboek van strafrecht ( KUHP) yakni "universitas delinguere non potest" atau "societas delinguere non potest" yaitu badan hukum tidak dapat melakukan tindak pidana.

Sifat korporasi yang ekspansif, berupaya berkembang menjadi besardan semakin besar dengan membeli atau menjual saham-saham dari atau kepada pihak swasta maupun pemerintah.

Secara etimologis, pengertian korporasi yang dalam istilah lain dikenal dengan corporatie

(Belanda), Corporation (Inggris), korporation (Jerman), berasal dari bahasa latin yaitu corporatio. "Corporation" sebagai kata benda (subatantivum) berasal dari kata kerja "corporare" yang banyak dipakai orang pada jaman abad pertengahan atau sesudah itu. "Corporate" sendiri berasal dari kata "corpus" (badan), yang berarti memberikan badan atau membadankan. Dengan demikian, maka akhirnya "corporatio" itu berarti hasil yang dijadikan orang, badan yang diperoleh dengan perbuatan manusia sebagai lawan 
terhadap badan manusia, yang terjadi menurut alam.

\section{Pengertian Memperkaya Diri}

Pengertian memperkaya diri sendiri atau orang lain atau suatu korporasi menurut penjelasan UndangUndang Nomor 31 Tahun 1999 jo UndangUndang Nomor 20 Tahun 2001 tentang Pemberantasan Tindak Pidana Korupsi, dapat berarti subyek hukum dari tindak pidana ini menjadi kaya atau bertambah harta kekayaannya, sedangkan pengertian memperkaya orang lain atau korporasi dapat diartikan sebagai perbuatan subyek hukum menjadikan orang lain atau korporasi menjadi kaya atau bertambah harta (aset) kekayaannya.

Menurut Sudarto, perbuatan memperkaya artinya berbuat apa saja, misalnya mengambil, memindahbukukan, menandatangani kontrak dan sebagainya, sehingga si pembuat bertambah kekayaannya.

Berbeda dengan Undang-Undang Nomor 31 Tahun 1999 jo Undang-Undang Nomor 20 Tahun 2001 di atas, justru Undang-Undang Nomor 20 Tahun 2001 di atas, justru Undang-Undang Nomor 3 Tahun 1971 memberikan penjelasan tentang pengertian rumusan unsur "Perbuatan memperkaya diri sendiri atau orang lain atau suatu badan", yang tercantum didalam pasal 1 sub a, dengan melihat pasal 18 ayat 2 yang mengatur kewajiban terdakwa untuk memberikan keterangan tentang sumber kekeyaannya sedemikian rupa, sehingga kekayaan yang tidak seimbang penghasilannya, atau penambahan kekayaan tersebut dapat dipergunakan untk memperkuat keterangan saksi lain bahwa terdakwa telah melakukan tindak pidana korupsi.

\section{Pengertian dapat Merugikan Keuangan} Negara dan atau Perekonomian Negara

Pengertian keuangan negara dari perspektif pidana diatur di dalam penjelasan pasal 2 ayat 1 Undang-Undang Nomor 31 Tahun 1999 jo Undang-Undang Nomor 20 Tahun 2001 tentang Pemberantasan Tindak Pidana Korupsi, seperti telah dikemukakan di dalam Perubahan sub bab ini adalah seluruh kekayaan negara falam bentuk apapun yang dipisahkan atau tidak dipisahkan, termasuk di dalamnya segala bagian kekayaan negara dan segala hak dan kewajiban yang timbul karena :

a. Berada dalam penguasaan, pengurusan dan pertanggungjawaban pejabat lembaga negara, baik ditingkat pusat maupun di daerah.

b. Berada dalam penguasaan, pengurusan dan pertanggungjawaban BUMN, BUMD, Yayasan, Badan Hukum, dan perusahaan yang menyertakan modal negara, atau perusahaan yang menyertakan modal dari pihak ketiga berdasarkan perjanjian dengan negara.

c. Pasal 2 merinci bentuk - bentuk keuangan negara yang dimaksud Pasal 1 angka 1 di atas, meliputi :

a. Hak negara untuk memungut pajak, mengeluarkan dan mengedarkan uang, dan melakukan pinjamanl;

b. Kewajiban negara untuk menyelenggarakan tugas layanan umum pemerintahan negara dan membayar tagihan pigak ketiga; 
Fitria Kusumawardhani, Pertanggungjawaban Koorporasi PT Bank BNI, Tbk, dalam Kredit Macet Berdasarkan Undang-undang Nomor 20 Tahun 2001 tentang Koorporasi

c. Penerimaan Negara;

d. Pengeluaran Negara;

e. Penerimaan Daerah;

f. Pengeluaran Daerah;

g. Kekayaan negara/kekayaan daerah yang dikelola sendiri atau oleh pihak lain berupa uang, surat berharga, piutang, barang, serta hak-hak lain yang dapat dinilai dengan uang, termasuk kekayaan yang dipisahkan pada perusahaan negara/ perusahaan daerah;

h. Kekayaan pihak lain yang dikuasai oleh pemerintah dalam rangka penyelenggaraan tugas pemerintahan dan/atau kepentingan umum;

i. Kekayaan pihak lain yang diperoleh dengan menggunakan fasilitas yang diberikan pemerintah.

Perspektif kerugiaan negara berdasarkan perspektif hukum pidana adalah suatu perbuatan yang menyimpang terhadap penggunaan dan pengelolaan keuangan negara sehingga dapat dikualifikasikan sebagai perbuatan merugikan negara atau dapat merugikan negara sebagai tindak pidana korupsi, dengan pemenuhan unsur-unsur :

1. Perbuatan tersebut merupakan perbuatan melawan hukum, baik dalam pengertian formil dan dapat dilengkapi dengan pengertian materiil atau penyalahgunaan wewenang kesempatan atau sarana yang ada padanya, dan

2. Para pihak ada yang diperkaya dan diuntungkan, baik si pelaku sendiri, orang lain atau korporasi (pasal 2 ayat 1 dan pasal 3 Undang-Undang Nomor
31 Tahun 1999 jo Undang-Undang Nomor 20 Tahun 2001)

Komparasi pengertian kerugian negara adalah berdasarkan perspektif hukum administrasi negara, yaitu kerugian negara yang memaknai pengertian keuangan negara, walaupun pengertian ini berbeda dengan kerugiaan negara yang terdapat dalam UndangUndang Nomor 31 Tahun 1999 jo Undang-Undang Nomor 20 Tahun 2001 tentang Pemberantasan Tindak Pidana Korupsi, tetapi pengertian dari perspektif hukum pidana adalah pengertian yang spektif dan merupakan lex specialis derogat legi generalis sistematis sebagai wujud dari asas logische specialiteit yaitu meskipun sama-sama bersifat khusus, tetapi yang mendominasi adalah lingkup kepentingannya dalam hal ini adalah pidana terkait dengan instrumen pengembalian kerugian negara, dalam tataran penerapannya harus melihatn kepada lingkup permasalahannya, jika menyangkut masalah pidana maka yang diberlakukan adalah hukum pidana, begitu juga terhadap masalah hukum perdata dan administrasi negara.

Delik formil di atas berarti kata "dapat" di dalam rumusan kedua pasal ini, tidak dapat ditafsirkan secara sempit, mengingat kata "dapat" padanannya adalah kata "bisa", atau dengan kata lain "potensi", bukan "mungkin", kata "dapat" mengandung adanya suatu kepastian dan terukur, tidak bersifat abstrak, untuk menentukan dapat tidaknya atau bisa tidaknya keuangan negara dirugikan perlu diketahui berapa besar potensi dari kerugian tersebut ( potensial lost) yang ditimbulkan oleh perbuatan tersangka atau terdakwa terukur, untuk 
mendapatkan ukuran potensial lost tentunya diperlukan audit terlebih dahulu, terkait dengan bank jika hal itu menyangkut kredit macet, potensi kerugian keuangan negara, selayaknya diketahui. Apalagi, jika debitur pernah memnuhi kewajibannya sebelumnya macet, maka tidak hanya sekedar dilakukan audit tetapi juga dilakukan taksasi harga terhadap aset-aset atau jaminan yang diberikan oleh debitur, selisih perhitungan dari keduanya inilah yang merupakan potensi, yang dikualifisir sebagai dapat.

Bagi pihak terafiliasi murni swasta, seperti Pemegang Saham atau Direksi yang menyelewengkan dana nasabah, prediksi kerugian keuangan negara baru dapat diketahui, jika dana talangan yang merupakan program pembayaran jaminan dari pemerintah berdasarkan Keputusan Presiden Nomor 26 Tahun 1998 tanggal 26 Januari 1998, terhadap para nasabah dapat diketahui besarnya, besarnya jumlah talangan yang dimaksud dengan potensial lost atau yang disebut dengan "dapat merugikan keuangan negara."

Konsekuensi logis dari delik formil unsur dapat merugikan keuangan negara atau perekonomian negara sebagai salah satu unsur inti (bestandeel) harus dibuktikan, surat dakwaan Jaksan Penuntut Umum mensyaratkan pencantuman perkiraan kerugian tersebut, yang tentunya harus didukung bukti-bukti yang dapat diterima oleh akal sehat.

Pasal 3, Undang-Undang Nomor 31 Tahun 1999 tentang Pemberantaan Tindak Korupsi di ancam dengan pidana penjara seumur hidup atau pidana penjara paling singkat 1 (satu) Tahun dan paling lama 20 (dua puluh) Tahun dan atau denda paling sedikit Rp 50.000.000 (lima puluh juta rupiah) dan paling banyak Rp 1.000.000.000 (satu miliar rupiah). Unsurnya terdiri :

a. Setiap orang

b. Dengan tujuan menguntungkan diri sendiri atau orang lain atau suatu korporasi

c. Menyalahgunakan kewenangan, kesempatan, atau sarana yang ada padanya karena jabatan atau kedudukan

d. Dapat merugikan keuangan negara atau perekonomian negara

Subyek hukum pada pasal ini pengertiannya berbeda dengan pengertian "setiap orang" pada pasal 2 ayat 1 . Di sini titik beratnya hanya pada Pegawai Negeri yang perbuatannya terkait dengan kewenangan, kesempatan atau sarana yang ada padanya karena jabatan atau kedudukannya.

Pasal 8 Undang-Undang Nomor 20 Tahun 2001 tentang Pemberantasan Tindak Pidana Korupsi Dipidana dengan pidana penjara paling singkat 3 (tiga) tahun dan paling lama 15 (lima belas) tahun dan pidana denda sedikit Rp150.000.000,00 (seratus lima puluh juta rupiah) dan paling banyak Rp750.000.000,00 (tujuh ratus lima puluh juta rupiah), pegawai negeri atau orang selain pegawai negeri yang ditugaskan menjalankan suatu jabatan umum secara terus menerus atau untuk sementara waktu, dengan sengaja menggelapkan uang atau surat berharga yang disimpan karena jabatannya, atau membiarkan uang atau surat berharga tersebut diambil atau digelapkan oleh orang lain, atau membantu dalam melakukan perbuatan tersebut. 
Fitria Kusumawardhani, Pertanggungjawaban Koorporasi PT Bank BNI, Tbk, dalam Kredit Macet Berdasarkan Undang-undang Nomor 20 Tahun 2001 tentang Koorporasi

\section{Pengertian Menguntungkan Diri Sendiri}

Pengertian menguntungkan diri sendiri adalah menambah harta kekayaan atau harta benda atau dapat juga diartikan telah menikmati hasil-hasil yang diperolehnya dari perbuatan menyalahgunakan kewenangan, kesempatan atau sarana yang ada padanya karena jabatan atau kedudukan, sedangkan menurut Sudarto, merupakan unsur batin yang menentukan arah dari perbuatan penyalahgunaan dan sebagainya, adanya unsur ini harus pula ditentukan secara obyektif dengan memperhatikan segala keadaan lahir yang menyertai perbuatan tersangka.

Untuk mengkonstatir suatu perbuatan memenuhi rumusan unsur menguntungkan diri sendiri, orang lain atau suatu korporasi harus nyata-nyata terlihat actus reus dan mens rea yaitu adanya perbuatan lahir yang terlarang atau melawan hukum dan mampu bertanggung jawab secara pidana atau dengan kata lain sikap batin yang mengikuti perbuatannya tersebut memang jahat dan pelakunya memiliki kemampuan bertanggung jawab.

Bagi para pelaku bisnis maupun eksekutif bank, ketika mereka dituding dan dituntut melakukan tindak pidana korupsi akan berkelit dengan doktrin Business Judgement Rule yang dijadikan alasan untuk menghindarkan pertanggungjawaban pidana, menjadikan doktrin tersebut sebagai alasan, sah-sah saja asalkan hal itu murni risk business, tetapi jika itu merupakan human error nyata-nyata ada :
a. Kecurangan (deceit)
b. Manipula (manipulatie)

c. Penyesatan (misrepresentation)

d. Penyembunyian Kenyataan (concealment of fact)

e. Pelanggaran Kepercayaan (breach of trust)

f. Akal-akalan (subterfuge)

g. Pengelakan peraturan (illegal circumvention)

Pandangan Robert Charles Clark itu sejalan dengan ketentuan pasal 92 dan pasal $97 \quad$ Undang-Undang Nomor 40 Tahun 2007 tentang Perseroan Terbatas yang menentukan :

Pasal 92

(1) Direksi menjalankan pengurusan perseroan untuk kepentingan perseroan dan sesuai dengan maksud dan tujuan perseoran

(2) Direksi berwenang menjalankan pengurusan sebagaiman dimaksud pada ayat 1 sesuai dengan kebijakan yang dipandang tepat, dalam batas yang ditentukan dalam undangundang ini dan/atau anggaran dasar

Pasal 97

(1) Direksi bertanggung jawab atas pengurusan perseroan sebagaimana dimaksud dalam pasal 92 perseroan sebagaimana dimaksud dalam pasal 92 ayat 1

(2) Pengurusan sebagaimana dimaksud pada ayat 1 , wajib dilaksanakan setiap anggota direksi dengan itikad baik dan penuh bertanggung jawab

(3) Setiap anggota direksi bertanggung jawab penuh secara pribadi atas kerugian perseoran apabila yang bersangkutan bersalah atau lalai menjalankan tugasnya sesuai dengan ketentuan sebagaimana dimaksud pada ayat 2 (Marwan Effendy, 2013). 


\section{Kasus}

Kinerja kredit PT BANK NEGARA INDONESIA Tbk (BNI) yang kinclong pada 2016 harus diimbangi dengan peningkatan rasio bermasalah (Non Performing Loan/NPL) sepanjang tahun lalu. Tercatat, sepanjang 2016 angka NPL gross perseroan merangkak naik menjadi 3 persen dari posisi 2015 yang hanya sebesar 2,7 persen.

Direktur Business Banking BNI Putrama Wahju Setiawan mengatakan, peningkatan kredit macet tersebut diakibatkan oleh macetnya pembayaran kredit yang dilakukan oleh dua debitur segmen korporasi yang memiliki jumlah utang cukup besar. Kedua perusahaan tersebut adalah PT Trikomsel Oke Tbk dan PT Pan Maritime.

Putra mengatakan, saat ini kedua debitur tersebut masing-masing dalam masa Penundaan kewajiban pembayaran utang (PKPU) serta pailit. Kondisi tersebut membuat BNI tidak bisa menarik kembali pinjaman yang telah digelontorkan sebelumnya.

"untuk progress penanganannya debitur tersebut akan kita permasalahan secara hukum, Trikomsel sedang dalam kesepakatan melalui pengadilan niaga dan dari mulai awal tahun ini Trikomsel diharapkan dapat memenuhi kewajiban yang dituangkan dalam kesepakatan di pengadilan niaga tersebut."

Kendati demikian, bantaian modal BNI tahun lalu masih cukup untuk meredam peningkatan kredit macet. Hal ini tercermin dari tingkat kecukupan permodalan atau capital adequacy (CAR) tetap terjaga baik pada level 19,4 persen. Secara total NPL juga membaik dari 0,9 persen pada akhir tahun 2015 menjadi 0,4 persen pada akhir tahun 2016.

Secara fundamental, Cadangan Kerugian Penyusutan Nilai (CKPN) juga tetap terjaga dengan baik dengan tingkat coverage ratio naik dari 140,4 persen 2015 menjadi 146 persen pada 2016.

Kejaksaan Negeri (Kejari) Parepare menetapkan tersangka baru atas kredit macet BNI Parepare merugikan negara sebesar Rp 35 Miliar. Dia adalah Hendrik Jaury, Notaris yang berkantor di Jalan Sulawesi, Makasar.

"Penetapan tersangka Hendrik ini merupakan pengembangan, dia diduga terlibat dalam proses tidak diperpanjangnya Cover Note, sehingga BNI tidak bisa menyita aset yang menjadi jaminan kreditur bank."

Empat orang dalam kasus ini telah divonis. Masing-masing, mantan Analisis Kredit di Sentral Kredit Menengah Makasar yang juga relationship BNI Parepare, Asmiati Khumas, Kepala Cabang BNI Parepare, Syahminal Yonnidarma, Staf BNI Parepare, Gusdi Hasanuddin dan pemilik PT Griya Maricaya Gemilang, Aming Gozal (https://www.cnnindonesia.com/ekonom i/20170126180729-78-189299/kreditmacet-bni-meningkat-akibat-tunggakandua-debitur-jumbo, di akses pukul 12 Januari 2018).

\section{Analisa Kasus}

Pengertian korporasi menurut Black;s Law Dictionary, yaitu "An entity (usually a busines) having authority under law to act as a single person distinct from the shareholders who own it and having rights to issue stock and exist indefinitely, a group or succession of persons established 
Fitria Kusumawardhani, Pertanggungjawaban Koorporasi PT Bank BNI, Tbk, dalam Kredit Macet Berdasarkan Undang-undang Nomor 20 Tahun 2001 tentang Koorporasi

in accordance with legal rules into a legal or juristic person that has legal personality distinct from the natural persons who make it up, exists indefinitely apart from them and has the legal powers that is constitution gives it."

Hakekat penerapan pidana secara proporsional ini penting agar upaya mewujdukan Good Corporate Governance dalam konteks penegakan hukum tidak bias. Bahkan menjadi sangat penting saat ini untuk mensosialisasikan penegakan kejahatan korporasi karena mengemuka persoalan tersebut, agar masing-masing kita atau pihak-pihak terkait menjadi aware dengan masalah ini, sehingga penanganan dan langkah penyelesaian permasalahannya tepat, baik kepastian hukum bagi para pelaku korporasi maupun bagi masyarakat luas.

Menurut Sudarto, perbuatan memperkaya artinya berbuat apa saja, misalnya mengambil, memindahbukukan, menandatangani kontrak dan sebagainya, sehingga si pembuat bertambah kekayaannya.

Keterliban korporasi dalam tindak pidana diposisikan sebagai subyek hukum, tidak saja menimbulkan persoalan tentang hak melakukan tindak pidana, tetapi juga masalah-masalah pertanggungjawaban korporasi. Diterimanya korporasi dalam pengertian badan hukum atau konsep pelaku fungsional (functional daderschap) dalam hukum pidana merupakan perkembangan yang sangat maju dengan meggeser doktrin yang mewarnai wetboek van strafrecht (KUHP) yakni "universitas delinguere non potest" atau "societas delinguere non potest" yaitu badan hukum tidak dapat melakukan tindak pidana.
Dalam sejarah PT BANK BNI, Tbk, melalui Bursa Efek Jakarta (BEJ) Bani BNI Merupakan bank negara pertama yang gopublic. kasus kredit macet PT BANK BNI, Tbk. Definisi bank menurut Pasal 1 butir ke-2 Undang-Undang Nomor 7 Tahun 1992 sebagaimana telah diubah oleh Undang-Undang Perbankan Nomor 10 Tahun 1998 tentang Perbankan (yang selanjutnya disebut Undang-Undang Perbankan)

"Badan Usaha yang menghimpun dana dari masyarakat dalam bentuk simpanan dan meyalurkannya kepada masyarakat dalam kredit dan/atau bentuk-bentuk lainnya dalam rangka meningkatkan taraf hidup orang banyak."

Saat ini Bank BNI mengalami kasus kredit macet yang dilakukan oleh debiturdebitur yang mempunyai hutang cukup besar. Peningkatan kredit macet tersebut diakibatkan oleh macetnya pembayaran kredit yang dilakukan oleh dua debitur segmen korporasi yang memiliki jumlah utang cukup besar. Kedua perusahaan tersebut adalah PT Trikomsel Oke Tbk dan PT Pan Maritime.

Kejaksaan Negeri (Kejari) Parepare menetapkan tersangka baru atas kredit macet BNI Parepare merugikan negara sebesar Rp 35 Miliar. Dia adalah Hendrik Jaury, Notaris yang berkantor di Jalan Sulawesi, Makasar.

"Penetapan tersangka Hendrik ini merupakan pengembangan, dia diduga terlibat dalam proses tidak diperpanjangnya Cover Note, sehingga BNI tidak bisa menyita aset yang menjadi jaminan kreditur bank."

Notaris bertanggung jawab atas surat-surat dokumen sesuai dengan Undang-Undang Nomor 30 Tahun 2004 
Pasal 15 mengenai kewenangan notaris yang terdapat di dalam ayat (1) yang berbunyi :

"Notaris berwenang membuat akta otentik mengenai semua perbuatan, perjanjian dan ketetapan yang diharuskan oleh peraturan perundang-undangan dan/atau yang dikehendaki oleh yang berkepentingan untuk dinyatakan dalam akta otentik, menjamin kepatuhan tanggal pembuatan akta, menjamin kepastian tanggal pembuatan akta, menyimpan akta, memberikan grosse, salinan dan kutipan akta, semuanya itu sepanjang pembuatan akta-akta itu tidak juga ditugaskan atau dikecualikan kepada pejabat lain atau orang lain yang ditetapkan dalam undangundang."

Notaris berdasarkan UndangUndang Nomor 2 Tahun 2014

"Pasal 15 (1) Notaris berwenang membuat Akta autentik mengenai semua perbuatan, perjanjian, dan penetapan yang diharuskan oleh peraturan perundangundangan dan/atau yang dikehendaki oleh yang berkepentingan untuk dinyatakan dalam Akta autentik, menjamin kepastian tanggal pembuatan Akta, menyimpan Akta, memberikan grosse, salinan dan kutipan Akta, semuanya itu sepanjang pembuatan Akta itu tidak juga ditugaskan atau dikecualikan kepada pejabat lain atau orang lain yang ditetapkan oleh undangundang."

Dalam sistem alat bukti alat bukti "documentary" adalah yang dunia hukum kita indonesia dinamai "alat bukti tertulis". Alat bukti "material" adalah alat bukti dalam wujud benda konkret, selain pada alat bukti tertulis.

Cover

Note perpanjangan akta yang terdiri dari keterangan mengenai jangka waktu penyelesaian proses. Belum dapat disahkan disebabkan pengurusan di badan-badan terkait, disebabkan belum ada pengurusan di badan-badan terkait mengenai jaminan Bank BNI sehingga Bank BNI sebagai kreditur tidak bisa menggunakan jaminan sebagai aset jaminan pihak bank yang ini merupakan kekeliruan dari Bank BNI dengan menarik pihak ketiga yaitu notaris dalam hal ini Hendrik.

Menurut Penulis, PT BANK BNI, Tbk, mempunyai organisasi-organisasi yang bertanggung jawab berdasarkan Undang-Undang Nomor 40 Tahun 2007 tentang Perseroan Terbatas yakni dalam Pasal 97 :

(1) Direksi bertanggung jawab atas pengurusan perseroan sebagaimana dimaksud dalam pasal 92 perseroan sebagaimana dimaksud dalam pasal 92 ayat 1

(2) Pengurusan sebagaimana dimaksud pada ayat 1 , wajib dilaksanakan setiap anggota direksi dengan itikad baik dan penuh bertanggung jawab

(3) Setiap anggota direksi bertanggung jawab penuh secara pribadi atas kerugian perseoran apabila yang bersangkutan bersalah atau lalai menjalankan tugasnya sesuai dengan ketentuan sebagaimana dimaksud pada ayat 2 (Marwan Effendy, 2013).

Susunan organisasi Bank yaitu Direktur Utama, Komisaris, Anggota Komisaris, Manager Unit / Kepala Cabang, Pimpinan Unit, Analisis Kredit, Marketing Kredit, Administrasi, Accounting dan Staf.

Di dalam wilayah pusat (daerah) yang bertanggung jawab ialah Kepala Cabang, Pimpinan Unit, Analisis Kredit, 
Fitria Kusumawardhani, Pertanggungjawaban Koorporasi PT Bank BNI, Tbk, dalam Kredit Macet Berdasarkan Undang-undang Nomor 20 Tahun 2001 tentang Koorporasi

Marketing Kredit, Administrasi, Accounting dan Staf.

Berdasarkan susunan organisasi perbankan untuk pembantu cabang daerah, menurut penulis Kepala Cabang Parepare bernama Syahminal Yonnidarma, , Analisis Kredit di Sentral Kredit Menengah Makasar yang juga relationship BNI Parepare bernama Asmiati Khumas, Staf BNI Parepare bernama Gusdi Hasanuddin dan pemilik PT Griya Maricaya Gemilang bernama Aming Gozal memenuhi unsur Pasal 3 Undang-Undang Nomor 31 Tahun 1999 tentang Pemberantasan Tindak Pidana Korupsi di ancam dengan pidana penjara seumur hidup atau pidana penjara paling singkat 1 (satu) Tahun dan paling lama 20 (dua puluh) Tahun dan atau denda paling sedikit Rp 50.000.000 (lima juta rupiah) dan paling banyak Rp 1.000.000.000 (satu miliar rupiah).

Unsurnya terdiri :
a. Setiap orang
b. Dengan tujuan menguntungkan diri sendiri atau orang lain atau suatu korporasi
c. Menyalahgunakan kewenangan, kesempatan, atau sarana yang ada padanya karena jabatan atau kedudukan

d. Dapat merugikan keuangan negara atau perekonomian negara.

Negara menderita kerugian sebesar Rp 35.000.0000.000 (tiga puluh lima miliar rupiah). Merugikan keuangan negara atau perekonomian negara pada perspektif kerugiaan negara berdasarkan perspektif hukum pidana adalah suatu perbuatan yang menyimpang terhadap penggunaan dan pengelolaan keuangan negara sehingga dapat dikualifikasikan sebagai perbuatan merugikan negara atau dapat merugikan negara sebagai tindak pidana korupsi, dengan pemenuhan unsur-unsur : Perbuatan tersebut merupakan perbuatan melawan hukum, baik dalam pengertian formil dan dapat dilengkapi dengan pengertian materiil atau penyalahgunaan wewenang kesempatan atau sarana yang ada padanya.

Pasal 8 Undang-Undang Nomor 20 Tahun 2001 tentang Pemberantasan Tindak Pidana Korupsi Dipidana dengan pidana penjara paling singkat 3 (tiga) tahun dan paling lama 15 (lima belas) tahun dan pidana denda sedikit Rp150.000.000,00 (seratus lima puluh juta rupiah) dan paling banyak Rp750.000.000,00 (tujuh ratus lima puluh juta rupiah), pegawai negeri atau orang selain pegawai negeri yang ditugaskan menjalankan suatu jabatan umum secara terus menerus atau untuk sementara waktu, dengan sengaja menggelapkan uang atau surat berharga yang disimpan karena jabatannya, atau membiarkan uang atau surat berharga tersebut diambil atau digelapkan oleh orang lain, atau membantu dalam melakukan perbuatan tersebut.

\section{SIMPULAN}

Kesimpulan dari pertanyaan tersebut ialah pertanggungjawaban koorporasi dalam kasus ini Bank BNI Parepare dikenakan Pasal 8 UndangUndang Nomor 20 Tahun 2001 tentang Pemberantasan Tindak Pidana Korupsi Dipidana dengan pidana penjara paling singkat 3 (tiga) tahun dan paling lama 15 (lima belas) tahun dan pidana denda sedikit Rp150.000.000,00 (seratus lima puluh juta rupiah) dan paling banyak Rp750.000.000,00 (tujuh ratus lima puluh juta rupiah), pegawai negeri atau orang selain pegawai negeri yang 
ditugaskan menjalankan suatu jabatan umum secara terus menerus atau untuk sementara waktu, dengan sengaja menggelapkan uang atau surat berharga yang disimpan karena jabatannya, atau membiarkan uang atau surat berharga tersebut diambil atau digelapkan oleh orang lain, atau membantu dalam melakukan perbuatan tersebut.

\section{DAFTAR PUSTAKA}

Adib Bahari, Panduan Mendiriakn Perseroan Terbatas, Tim Pustaka Yustitisia, Yogyakarta, 2013.

Chartamarrasjid, Ais, Hukum Perbankan Nasional Indonesia, Prenada Media Group, Kencana, Jakarta, 2009.

Handri Raharjo, Cara Pintar Memilih dan Mengajukan Kredit, Cet. 1, Yogyakarta, Penerbit Yustisia, 2010.

https://www.cnnindonesia.com/ekonomi/201701 26180729-78-189299/kredit-macet-bnimeningkat-akibat tunggakan-dua-debiturjumbo, di akses pukul 12 Januari 2018.

Marwan Effendy, Korupsi \& Strategi Nasional : Pencagahan serta Pemberantasannya,GP Press Group, Jakarta, 2013.

Nainggolan, P.N.H., dan Isnaini, (2012), Analisis Terhadap Penetapan No: 01/Pen.Pdt.G/ Eks/HT/2010/ PN-PMS tentang Eksekusi Barang Jaminan olehBank dalam Penyelesaian Kredit Bermasalah, Mercatoria, 5 (1): 56-65

R.A. Emma Nurita, Cyber Notary : Pemahaman Awal dalam Konsep Pemikiran, PT. Refika Aditama, Bandung, 2012.

Rani Sri Agustina, Rahasia Bank, CV Keni Media, 2016, Bandung, Hal. 17.

Rendra Yozar Dharmaputra, dan Januari S., (2010), Pelaksanaan Perjanjian Kredit Modal Kerja di Bank Mandiri (PERSERO) Tbk. Cabang Binjai di Tinjau dari Undang-Undang Nomor 8 Tahun 1999 Tentang Perlindungan Konsumen, Mercatoria, 3 (2): 71-87

The Philosophy of Pancasila 